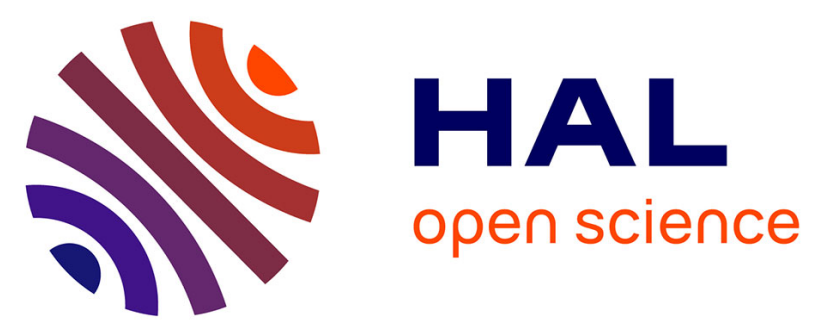

\title{
Trace elements in two odontocete species (Kogia breviceps and Globicephala macrorhynchus) stranded in New Caledonia (South Pacific)
}

Paco Bustamante, Claire Garrigue, Ludovic Breau, Florence Caurant, Willy Dabin, Jackie Greaves, Rémi Dodemont

\section{To cite this version:}

Paco Bustamante, Claire Garrigue, Ludovic Breau, Florence Caurant, Willy Dabin, et al.. Trace elements in two odontocete species (Kogia breviceps and Globicephala macrorhynchus) stranded in New Caledonia (South Pacific). Environmental Pollution, 2003, 124 (2), pp.263-271. 10.1016/S02697491(02)00480-3 . hal-00186634

\section{HAL Id: hal-00186634 https://hal.science/hal-00186634}

Submitted on 10 Nov 2007

HAL is a multi-disciplinary open access archive for the deposit and dissemination of scientific research documents, whether they are published or not. The documents may come from teaching and research institutions in France or abroad, or from public or private research centers.
L'archive ouverte pluridisciplinaire HAL, est destinée au dépôt et à la diffusion de documents scientifiques de niveau recherche, publiés ou non, émanant des établissements d'enseignement et de recherche français ou étrangers, des laboratoires publics ou privés. 
Trace elements in two odontocete species (Kogia breviceps and Globicephala macrorhynchus) stranded in New Caledonia (South Pacific).

P. Bustamante ${ }^{1 *}$, C. Garrigue ${ }^{2}$, L. Breau ${ }^{1,3}$, F. Caurant ${ }^{1}$, W. Dabin ${ }^{4}$, J. Greaves ${ }^{2}$, R. Dodemont ${ }^{2}$

${ }^{1}$ Laboratoire de Biologie et Environnement Marins, UPRES-EA 3168, Université de La Rochelle, 22, Avenue Michel Crépeau, F-17042 La Rochelle Cedex, France

${ }^{2}$ Opération Cétacés, BP 12827, 98802 Nouméa, New Caledonia

${ }^{3}$ Institut de Recherche pour le Développement (IRD), Centre de Nouméa, BP A5, 988485 Nouméa Cedex, New Caledonia

${ }^{4}$ Centre de Recherche sur les Mammifères Marins, Avenue Lazaret, Les Minimes, 17000 La Rochelle, France

Corresponding author: Dr. Paco Bustamante

Laboratoire de Biologie et d'Environnement Marins, EA 3168

Université de La Rochelle

22, Avenue Michel Crépeau

F-17042 La Rochelle (France)

Tel.: (+33) 546500294

Fax: (+33) 546500294

e-mail: pbustama@univ-lr.fr

* Corresponding author. Tel.:+33 546500 294; e-mail: pbustama@univ-lr.fr 
ABSTRACT: liver, muscle and blubber tissues of two short-finned pilot whales (Globicephala macrorhynchus) and two pygmy sperm whales (Kogia breviceps) stranded on the coast of New Caledonia have been analysed for 12 trace elements ( $\mathrm{Al}, \mathrm{Cd}, \mathrm{Co}, \mathrm{Cr}, \mathrm{Cu}, \mathrm{Fe}$, organic and total $\mathrm{Hg}, \mathrm{Mn}, \mathrm{Ni}, \mathrm{Se}, \mathrm{V}$, and $\mathrm{Zn}$ ). Liver was shown to be the most important accumulating organ for $\mathrm{Cd}, \mathrm{Cu}, \mathrm{Fe}, \mathrm{Hg}, \mathrm{Se}$, and $\mathrm{Zn}$ in both species, G. macrorhynchus having the highest $\mathrm{Cd}, \mathrm{Hg}, \mathrm{Se}$ and $\mathrm{Zn}$ levels. In this species, concentrations of total $\mathrm{Hg}$ are particularly elevated, reaching up to $1452 \mu \mathrm{g} \cdot \mathrm{g}^{-1} \mathrm{dwt}$. Only a very low percentage of the total $\mathrm{Hg}$ was organic. In both species, the levels of $\mathrm{Hg}$ are directly related to $\mathrm{Se}$ in liver. Thus, a molar ratio of $\mathrm{Hg}$ :Se close to 1.0 was found for all specimens, except for the youngest $K$. breviceps. Our results suggest that G. macrorhynchus have a physiology promoting the accumulation of high levels of naturally occurring toxic elements. Furthermore, concentrations of $\mathrm{Ni}, \mathrm{Cr}$ and $\mathrm{Co}$ are close to or below the detection limit in the liver and muscles of all specimens. This suggests that mining activity in New Caledonia, which typically elevates the levels of these contaminants in the marine environment, does not seem not to be a significant source of contamination for these pelagic marine mammals.

Keywords : Heavy metals ; Cadmium ; Mercury ; Nickel ; Marine Mammals ; Pacific Ocean 


\section{INTRODUCTION}

Heavy metals generally occur at very low concentrations in oceans (Bryan 1984). Nevertheless, most of marine organisms concentrate trace elements at higher concentrations than those occurring in their environment. This process, currently described as bioaccumulation, concerns toxic elements such as $\mathrm{Cd}$ or $\mathrm{Hg}$, as well as essential ones such as $\mathrm{Cu}, \mathrm{Fe}, \mathrm{Se}$, or $\mathrm{Zn}$. Slight variations of heavy metal concentrations in the environment of marine organisms could lead to a significant increase of their metal burdens. Enrichment of sea water in heavy metals may occur naturally by local environmental processes, such as volcanism or upwellings. In addition to this natural origin, human activities can lead to increases of trace element concentrations in coastal waters, subsequently leading to an increase of metal burdens in biota.

In New Caledonia, mining activities plus strong natural erosion due to tropical rainfall have resulted in enrichment of several metals in coastal waters (mainly $\mathrm{Co}, \mathrm{Cr}, \mathrm{Fe}$ and $\mathrm{Ni}$ ), and consequently in the coral reef food webs (Monniot et al. 1994). These authors reported high metal burdens in several species of filter-feeding ascidians from shallow waters. However, the impact of metal contamination does not appear to be limited to coastal waters and, in fact, high levels of $\mathrm{Co}, \mathrm{Cr}$ and $\mathrm{Ni}$ have also been reported in the tissues of a cephalopod living in deeper waters, the nautilus, Nautilus macromphalus (Bustamante et al. 2000).

Current literature on heavy metal concentrations in New Caledonian marine lower trophic level organisms is scarce (e.g. Monniot et al. 1994; Bustamante et al. 2000), and no data for marine mammals have been published to date. In this work, baseline information is presented for the concentrations of 12 trace elements in the tissues and organs of two odontocetes species, i.e., pygmy sperm whale, Kogia breviceps (de Blainville, 1838), and short-finned pilot whale, Globicephala macrorhynchus (Gray, 1846) for which very few information on trace elements are available. These marine mammals give the opportunity to investigate the 
impact of mining activities on high trophic level organisms stranded in New Caledonia. It also provides information on the bioaccumulation and detoxification processes of $\mathrm{Cd}$ and $\mathrm{Hg}$ in marine mammals from a tropical zone, toxic elements which are currently reported to raise the question of physiological damages in the tissues of top marine predators.

\section{MATERIALS AND METHODS}

\section{Sampling and sample preparation}

In spring 1997, two short-finned pilot whales (Globicephala macrorhynchus) and two pygmy sperm whales (Kogia breviceps) stranded on the coasts of New Caledonia. These animals were autopsied shortly after death. Stomach contents were collected and stored in 90\% ethanol for later diet analyses. Teeth were extracted for ageing and skin samples were collected for genetic analysis. Tissues and organs (liver, blubber and muscle) were sampled for heavy metal and radionuclides analyses (Garrigue et al. 2000). Separated tissue samples were placed in decontaminated glass vessels and stored at $-20^{\circ} \mathrm{C}$. They were then freezedried, finely ground and stored in plastic vials.

The two stranded G. macrorhynchus were probably part of a bigger pod observed in the vicinity of the stranding location on the day of stranding. This species is commonly encounter outside of the lagoon by long liners in both nearshore and pelagic environments but there is no evidence that they are resident in the area. In fact, seasonal inshore to offshore movements are related to the distribution of squid they feed on (Olson and Reily 2001).

Little is know on the status of $K$. breviceps in New Caledonia as they are very discrete animals, rarely observed alive. Most of the information on this species come from stranded 
animals which have been documented earlier in New Caledonia (Robineau and Rancurel 1981; Sylvestre 1988).

Age determination

Teeth were used for age determination, following the recommendations of Neilsen (1972) and Perrin and Myrick (1980). Teeth taken up from the lower jaw were cleaned, fixed and stored in $70 \%$ glycerined alcohol. Before sectioning and staining, teeth were decalcificated with

DC3 (Labonor@). Sections were then examined to count the growth layer groups (GLGs) assuming 1 GLG equals 1 years, as described by Perrin and Myrick (1980). Three series of several independent readings were done for each tooth section according to Hohn and Fernandez (1999). All readings were recorded to the nearest whole year and age was expressed as mean \pm SD for each individual.

Stomach contents analysis

Stomach contents were washed and the contained elements were sorted by type. Fish species were determined from the otoliths by J. Rivaton from the laboratory of marine biology of IRD (Nouméa, New Caledonia). Cephalopod species were determined from the beaks by Dr R. Young from the University of Hawaii.

\section{Metal analysis}

Metal analyses were performed by inductively coupled plasma atomic emission spectrophotometry (ICP-AES) for $\mathrm{Al}, \mathrm{Co}, \mathrm{Cr}, \mathrm{Cu}, \mathrm{Fe}, \mathrm{Mn}, \mathrm{Ni}, \mathrm{V}$ and $\mathrm{Zn}$, by atomic 
absorption spectrophotometry (AAS) for $\mathrm{Cd}, \mathrm{Cu}, \mathrm{Se}$ and $\mathrm{Zn}$, and with an Advanced Mercury Analyser (AMA) for total and organic $\mathrm{Hg}$ after extraction.

For ICP-AES measurements, 2 aliquots of approx. $500 \mathrm{mg}$ of each homogenised dry sample were digested in Teflon containers with $4 \mathrm{ml}$ of $65 \% \mathrm{HNO}_{3}$ and $1 \mathrm{ml}$ of $30 \% \mathrm{H}_{2} \mathrm{O}_{2}$ using a microwave digester (ANTON-PAAR, Perkin Elmer). The digested contents were made up to $25 \mathrm{ml}$ with Milli-Q quality water. Elements were analysed by ICP-AES with an OPTIMA 3200 DV, Perkin-Elmer. Multicomponent Spectral Fitting Models were used to correct for spectral interference between elements.

For AAS measurements, 2 aliquots of approx. $300 \mathrm{mg}$ of each homogenised dry sample were digested with $3.5 \mathrm{ml}$ of $65 \% \mathrm{HNO}_{3}$ at $60^{\circ} \mathrm{C}$ for $3 \mathrm{~d}$. The digested contents were then diluted to $10 \mathrm{ml}$ in Milli-Q quality water. $\mathrm{Cd}, \mathrm{Cu}, \mathrm{Se}$ and $\mathrm{Zn}$ were assayed using flame and graphite furnace atomic absorption spectrophotometer Varian 250 Plus with deuterium background correction.

For AMA measurements, aliquots ranging from 10 to $50 \mathrm{mg}$ of dried material were analysed directly for total $\mathrm{Hg}$ in a Advanced Mercury Analyser spectrophotometer (Altec AMA 254). $\mathrm{Hg}$ determination involved evaporation of $\mathrm{Hg}$ by progressive heating until $800^{\circ} \mathrm{C}$ was reached and then held under oxygen atmosphere for $3 \mathrm{~min}$, and subsequent amalgamation on a Au-net. Afterwards, the net was heated to liberate the collected mercury, subsequently measured by UV atomic absorption spectrophotometry. The same procedure was performed for the analysis of organic $\mathrm{Hg}$ after extraction adapted from Uthe et al. 1972. Organic $\mathrm{Hg}$ was extracted from 2 aliquots of approx. $500 \mathrm{mg}$ of each homogenised dry sample using $2 \mathrm{ml}$ of acidic sodium bromide $\left(30 \% \mathrm{NaBr}\right.$ in $\left.4 \mathrm{~N} \mathrm{H}_{2} \mathrm{SO}_{4}\right), 4 \mathrm{ml}$ of cupric sulfate $\left(2.5 \% \mathrm{CuSO}_{4}\right.$ in milli-Q quality water) and $10 \mathrm{ml}$ of toluene under agitation for $10 \mathrm{~min}$ in glass flasks. The organic phase was then separated and used for the analysis in the AMA. 
Quality control was assured using dogfish liver DOLT-2 (NRCC) and dogfish muscle DORM-2 (NRCC) as reference materials for AAS and AMA, and dogfish muscle DORM-1 (NRCC) for ICP-AES. These standards were treated and analysed under the same conditions as the samples. The results were in good agreement with the certified values (Table 1). Detection limits $\left(\mu \mathrm{g} \cdot \mathrm{g}^{-1}\right)$ were 0.004 for $\mathrm{Cd}, 0.5$ for $\mathrm{Cu}, 3$ for $\mathrm{Zn}, 0.8$ for $\mathrm{Se}, 0.005$ for total $\mathrm{Hg}$ and 0.2 for organic $\mathrm{Hg}$ for AAS and AMA analyses. For ICP-AES analyses, detection limits were 0.006 for $\mathrm{Al}, 0.040$ for $\mathrm{Co}, 0.013$ for $\mathrm{Cr}, 0.005$ for $\mathrm{Cu}, 0.051$ for $\mathrm{Fe}, 0.002$ for $\mathrm{Mn}, 0.010$ for $\mathrm{Ni}, 0.009$ for $\mathrm{V}$ and 0.008 for $\mathrm{Zn}\left(\mu \mathrm{g} \cdot \mathrm{g}^{-1}\right)$. Metal concentrations in tissues are reported in $\mu \mathrm{g} \cdot \mathrm{g}^{-1}$ dry wt.

\section{RESULTS}

Main features, age and diet

The main features of the 4 specimens sampled, one male and one female G. macrorhynchus and one male and one female $K$. breviceps, are reported in Table 2, with the prey species identified from their corresponding stomach contents and their ages. Considering their ages, the two G. macrorhynchus may have been sexually matured as sexual maturity occurred at 9 years for females and between 13 and 16 for males (Olson and Reilly, 2001). Considering $K$. breviceps, the size of sexual maturity have been documented to be $2.7 \mathrm{~m}$ to $3.0 \mathrm{~m}$ for males and 2.6 to $2.8 \mathrm{~m}$ for females of (Leatherwood et al., 1983). Furthermore, K. breviceps appears to reach sexual maturity between 3 and 5 years old (Plön, in prep.). In the light of this data the two $K$. breviceps presented in this paper may have been sexually matured.

All the animals with the exception of the male $K$. breviceps were already stranded when samples were collected. This last one was first alive, but it has been euthanasied after the 
failure of its refloat. The autopsies didn't provide any evident reasons for the death of the animals. Parasites were only found in great quantity in the male $K$. breviceps, with a stomach full of Anisakis simplex (Nematodes). This specimen could have suffered of a parasitose, stranded individuals from this species being frequently heavily infected by intestinal nematodes (McAlpine, 2002).

On the other hand, the female G. macrorhynchus was probably pregnant before the stranding as part of a fotus was found in its vicinity. This female may have been fasting as its stomach was empty (Table 2).

\section{Metal analysis}

Heavy metal and organic mercury concentrations in the liver, muscle and blubber of $G$. macrorhynchus and $K$. breviceps are presented in Table 3. Co, $\mathrm{Cr}$ and $\mathrm{Ni}$ concentrations in all tissues and organs fall below the detection limit or close to it (i.e. in liver). Among these tissues, liver is the most important accumulating organ for $\mathrm{Cd}, \mathrm{Cu}, \mathrm{Fe}, \mathrm{Hg}, \mathrm{Se}$, and $\mathrm{Zn}$ and to a lesser extent for Mn and V. However, the two G. macrorhynchus exhibit higher hepatic levels for $\mathrm{Cd}, \mathrm{Cu}, \mathrm{Hg}$, Se and $\mathrm{Zn}$ than $K$. breviceps while both species have similar hepatic levels of $\mathrm{Mn}$ and $\mathrm{V}$. Fe is the only metal having higher concentrations in the liver of $K$. breviceps than in the one of G. macrorhynchus.

In muscle, $\mathrm{Mn}$ in G. macrorhynchus and $\mathrm{V}$ in both mammals are below the detection limits. The remaining trace elements were within the same order of concentration in the muscle of both species (Table 3). The only exception was $\mathrm{Hg}$, where concentrations were 5 times higher in G. macrorhynchus muscle compared to K. breviceps. 
Blubber has generally low trace element concentrations. However, $\mathrm{Cr}$ exhibits the highest concentrations among the three tissues (Table 3). Despite its strong affinity to lipids, organic $\mathrm{Hg}$ concentrations in blubber were an order of magnitude lower than in liver and muscle.

Figure 1 shows the hepatic concentrations of inorganic $\mathrm{Hg}$ and $\mathrm{Se}$ of marine mammals in relation to age together with the inorganic $\mathrm{Hg}$ :Se molar ratio for each individual. In both species, hepatic inorganic $\mathrm{Hg}$ is directly related to hepatic Se. Consequently, a molar ratio close to 1.0 is found in all specimens, except for the youngest $K$. breviceps (6 years old) for which this ratio was 0.13 (Figure 1). Nevertheless, both species exhibit very different ratio organic:total $\mathrm{Hg}$ in their tissues (Figure 2) with $K$. breviceps showing a higher percentage of organic $\mathrm{Hg}$ than G. macrorhynchus in liver (aver. $13 \%$ vs $0.5 \%$ ) and in muscle (aver. $75 \%$ vs $14 \%)$.

\section{DISCUSSION}

\section{Trace element levels}

Heavy metal concentrations in the tissues of marine mammals are globally well documented but they concern mainly species having strong interactions with man, i.e. hunted for meat consumption, by-caught during fishing or living in coastal areas. Furthermore, very few studies have investigated trace elements such as $\mathrm{Co}, \mathrm{Cr}, \mathrm{Ni}$ or $\mathrm{V}$ although they are potentially toxic, probably because these trace elements are not bioaccumulated in large amounts in mammalian tissues (Thompson 1990). Nevertheless, such elements can be used as tracers of contamination when an enrichment due to anthropogenic activities occurs. In Alaska, Mackey et al. (1996) have shown an increase of $\mathrm{V}$ in the tissues of pinnipeds and cetaceans. The 
bioaccumulation of $\mathrm{V}$ in biota and its transfer to the top marine predators has been related to the contamination of sea water by oil residues in this area. Similarly, the consequence of intense mining activities in New Caledonia must be monitored by the measurement of the concentrations of $\mathrm{Ni}$ and its associated elements, mainly $\mathrm{Co}$ and $\mathrm{Cr}$, in the food webs around the island. Analysis in the tissues of the short-finned pilot whales Globicephala macrorhynchus and the pygmy sperm whales Kogia breviceps have not revealed any increase of concentrations for these three metals compared to other marine mammals species from various areas (Table 4). With the exception of $\mathrm{Cr}$ in the blubber of the male $G$. macrorhynchus $\left(2.51 \mu \mathrm{g} \cdot \mathrm{g}^{-1} \mathrm{dwt}\right)$, concentrations remained close to or below the detection limits. Considering that these pelagic animals could have preyed on species living around the island as suggested by the examination of their full stomach, our results suggest that these metals are not easily transferred in the food web of these pelagic odontocetes. To assess the impact of mining activities on marine mammals, further studies should be conducted on more coastal species known to be resident of the impacted area, such as the bottlenose dolphin (Tursiops truncatus) or the dugong (Dugong dugon) that spend all their life in the waters of the New Caledonian lagoon.

Most of the studies on the bioaccumulation of trace elements in marine mammals have focused on toxic $\mathrm{Cd}$ and $\mathrm{Hg}$, which are well bioaccumulated in mammalian tissues (Thompson 1990). Nevertheless, numerous rare species have been poorly investigated and there is a lack of data for G. macrorhynchus and K. breviceps. Table 5 shows the paucity of information reported for these two species. The present study provides new information on metal concentrations in these marine mammals. The four odontocetes stranded in New Caledonia exhibited very high levels of Cd and $\mathrm{Hg}$ in liver, reaching 464 and $1452 \mu \mathrm{g} \cdot \mathrm{g}^{-1} \mathrm{dwt}$, respectively. However, G. macrorhynchus displayed much higher concentrations of $\mathrm{Cd}$ and Hg than K. breviceps (Table 3). 
Both species occupy a high and similar trophic levels (4.3 and 4.4 for G. macrorhynchus and K. breviceps, respectively), assessed by stable isotope analysis (Pauly et al. 1998). They mainly prey upon squid although this may be implemented by a large proportion of fish for $G$. macrorhynchus (around 40\%) and a lower one for K. breviceps (around 20\%) in certain areas (Pauly et al. 1998). The concentrations of $\mathrm{Hg}$ in the liver of G. macrorhynchus sampled in New Caledonia suggest that fish constitute an important prey items for this species as fish are considered to be the main $\mathrm{Hg}$ source for marine top predators (Law et al. 1992). This was confirmed by the analysis of stomach contents showing several fish species in the diet of $G$. macrorhynchus (Table 2). However, no fish remains were found in the stomach contents of $K$. breviceps but its diet included several crustaceans species which are known to have very low Hg contents (Cossa et al. 1990).

Similar exposures to Cd would occur for both species considering the high dietary intakes due to cephalopod consumption (Bustamante et al. 1998) that represent $60 \%$ and $75 \%$ of the diet of G. macrorhynchus and K. breviceps, respectively (Pauly et al. 1998). Nevertheless, G. macrorhynchus had hepatic Cd concentrations of one order of magnitude higher than $K$. breviceps (Table 3). It appears from the scarce data available in the literature that $K$. breviceps generally have lower Cd concentrations than G. macrorhynchus (Table 5). This suggests that diet does not explain alone the high concentrations of $\mathrm{Cd}$ in the tissues of G. macrorhynchus and that a particular physiology promoting the accumulation of naturally occurring $\mathrm{Cd}$ could be envisage for this species.

\section{Detoxification processes}

Extremely high levels of toxic $\mathrm{Hg}$ and $\mathrm{Cd}$ may trigger cellular and physiological damages of the target organs, especially kidney (Gallien et al. 2001). Despite the lack of the main storage organ for $\mathrm{Cd}$ analyses (i.e. kidney), Cd concentrations encountered here in liver suggest even 
higher concentrations in kidney as it is always the case in marine mammals (Aguilar et al. 1999). Renal dysfunction has been linked to Cd concentrations in liver exceeding $20 \mu \mathrm{g} . \mathrm{g}^{-1}$ wwt (approx. $100 \mu \mathrm{g} \cdot \mathrm{g}^{-1} \mathrm{dwt}$ ) (Honda 1985, Fujise et al. 1988). G. macrorhynchus had Cd concentrations in liver far higher than that limit (i.e. 225 and $464 \mu \mathrm{g} . \mathrm{g}^{-1} \mathrm{dwt}$ ), while the livers of $K$. breviceps were clearly below that limit (Table 3). Thus, Cd detoxification processes should be particularly efficient in the liver and kidney of G. macrorhynchus to support such high concentrations and needs to be investigated further.

Marine mammals are exposed to methyl $\mathrm{Hg}$ through fish consumption, but only a small fraction of the total $\mathrm{Hg}$ in liver and muscle of G. macrorhynchus was found to be organic $\mathrm{Hg}$, i.e. $<1 \%$ and $<15 \%$ of the total $\mathrm{Hg}$, respectively (Fig. 2). This is far below the percentage of organic $\mathrm{Hg}$ to total $\mathrm{Hg}$ that is usually found in these tissues of adult marine mammals, which generally ranges from 3 to $20 \%$ for liver and from 70 to $95 \%$ for muscle (Caurant et al. 1996, Wagemann et al. 1998). Gaskin et al. (1974) also reported values ranging from 2 to $17 \%$ for organic $\mathrm{Hg}$ in the liver of G. macrorhynchus from the Lesser Antilles, but muscle had only 42 to $60 \%$ of total $\mathrm{Hg}$ in the organic form. Therefore, organic $\mathrm{Hg}$ concentrations in liver and muscle of G. macrorhynchus from New Caledonia are relatively similar to those from Lesser Antilles (Gaskin et al. 1974). Apparently, the low fraction of hepatic organic Hg appear to be due to very high total $\mathrm{Hg}$ concentrations. However, such a low organic fraction in muscle of G. macrorhynchus from New Caledonia remains questionable. It has been suggested that residual mercury could be mobilised and concentrated from muscle and blubber in other tissues prior to death in G. macrorhynchus from the Cumberland Islands (Stoneburner 1978). This author explained that a stress period, viz. fast, could lead to such remobilization. The very low percentages of organic $\mathrm{Hg}$ in blubber support this speculation.

It is noteworthy that $K$. breviceps preferentially feeding on cephalopods and shrimp (Table 2), had concentrations of organic $\mathrm{Hg}$ in their tissues similar to that of G. macrorhynchus. 
Cephalopods and shrimp displayed lower methyl $\mathrm{Hg}$ contents than fish, i.e. from 29 to $55 \%$ vs 53 to $94 \%$, respectively (Cappon \& Smith 1982). Compared to G. macrorhynchus, higher percentages of organic $\mathrm{Hg}$ in the tissues of $\mathrm{K}$. breviceps related to lower total $\mathrm{Hg}$ contents in liver could be explained by a lower rate of hepatic demethylation. Low percentages of methyl $\mathrm{Hg}$ in liver have been reported for many marine mammals species (e.g. Itano et al. 1984, Wagemann et al. 1998). This supports the idea of continuous demethylation of methyl $\mathrm{Hg}$ occurring in liver throughout the animal's life span, subsequently leading to the formation of mercuric selenide (HgSe) granules (Pelletier 1985, Cuvin-Aralar \& Furness 1991, Nigro \& Leonzio 1996). HgSe granules (tiemannite) have been identified in the liver of seabirds, marine mammals and humans (Martoja \& Berry 1980, Pelletier 1985, Hansen et al. 1989, Nigro \& Leonzio 1996). Moreover, many studies also reported that $\mathrm{Hg}$ and Se are correlated in a 1:1 molar ratio as in HgSe (Koeman et al. 1973, Nielsen \& Dietz 1990, Law et al. 1997, Wagemann et al. 1998). G. macrorhynchus and K. breviceps from New Caledonia had a $\mathrm{Hg}$ :Se molar ratio close to 1 and a low percentage of organic $\mathrm{Hg}$ in liver (Fig. 1 \& 2). This suggests the presence of tiemannite granules as a result of demethylation of organic $\mathrm{Hg}$ in liver. However, the youngest $K$. breviceps, a 6 years old male (Table 2), had a low hepatic $\mathrm{Hg}$ :Se ratio due to low total $\mathrm{Hg}$ concentrations. This specimen also exhibited an elevated percentage of hepatic organic $\mathrm{Hg}$ (Fig. 2). Palmisano et al. (1995) have shown that demethylation of $\mathrm{Hg}$ by Se is efficient reaching a threshold $\mathrm{Hg}$ concentration of $100 \mu \mathrm{g} \cdot \mathrm{g}^{-1}$ wwt (approx. $500 \mu \mathrm{g} \cdot \mathrm{g}^{-1} \mathrm{dwt}$ ) in the liver of the dolphin Stenella coeruleoalba. Although this threshold should be different from one species to another, it clearly appears that the young $K$. breviceps had $\mathrm{Hg}$ concentrations far below such a threshold. 
The present study provides new information on trace elements concentrations in the tissues of two rare marine mammals species from a tropical area. Very low $\mathrm{Ni}$, $\mathrm{Co}$ and $\mathrm{Cr}$ concentrations in the tissues of $G$. macrorhynchus and $K$. breviceps suggest that industrial extracting activities in New Caledonia does not represent a significant source of contaminants for these two particular species. On the other hand, very high $\mathrm{Cd}$ and $\mathrm{Hg}$ concentrations in the liver of these marine mammals were related to cephalopod and fish consumption. Interspecific differences in the bioaccumulation, i.e. highest $\mathrm{Cd}$ and $\mathrm{Hg}$ concentrations in $G$. macrorhynchus, remain questionable and should be related to the physiology of this species.

Acknowledgements. We are particularly grateful to Richard Young from the University of Hawaii for cephalopod determination and to Jacques Rivaton from the IRD of Nouméa for fish determination. We also thanks the four anonymous reviewers for their helpful comments on this work.

\section{REFERENCES}

Aguilar, A., Borrell, A., Pastor, T., 1999. Biological factors affecting variability of persistent pollutant levels in cetaceans. In: Chemical pollutants and cetaceans, Reijnders PJH, Aguilar A, Donovan GP (Eds.), The journal of Cetacean Research and Management, Special Issue 1, 83-116.

Bryan, G.W., 1984. Pollution due to heavy metals and their compounds. In: Kinne, O. (Ed.), Marine Ecology, vol. 5 Part 3. Chichester, Wiley-Interscience, pp. 1289-1431.

Bustamante, P., Caurant, F., Fowler, S.W., Miramand, P., 1998. Cephalopods as a vector for the transfer of cadmium to top marine predators in the north-east Atlantic Ocean. The Science of the Total Environment 220, 71-80. 
Bustamante, P., Grigioni, S., Boucher-Rodoni, R., Caurant, F., Miramand, P., 2000. Bioaccumulation of 12 trace elements in the tissues of the nautilus Nautilus macromphalus from New-Caledonia. Marine Pollution Bulletin 40(8), 688-696.

Cappon, C.J., Smith, J.C., 1982. Chemical form and distribution of mercury and selenium in edible seafood. Journal of Analytical Toxicology 6, 10-21.

Cardellicchio, N., Giandomenico, S., Ragone, P., Di Leo, A., 2000. Tissue distribution of metals in striped dolphins (Stenella coeruleoalba) from the Apulian coasts, Southern Italy. Marine Environmental Research 49, 55-66.

Caurant, F., Navarro, M., Amiard, J.C., 1996. Mercury in pilot whales: possible limits to the detoxification process. The Science of the Total Environment 186, 95-104.

Cossa, D., Thibaud, Y., Roméo, M., Gnassia-Barelli, M., 1990. Le mercure milieu marin. Biogéochimie et écotoxicologie. Rapport Scientifique et Techniques de l'IFREMER, Brest, $130 \mathrm{p}$

Cuvin-Aralar, M.L.A., Furness, R.W., 1991. Mercury and selenium interactions: a review. Ecotoxicology and Environmental Safety 21, 348-364.

Fujise, Y., Honda, K., Tatsukawa, R., Mishima, S., 1988. Tissue distribution of heavy metals in Dall's porpoise in the northwestern Pacific. Marine Pollution Bulletin 19, 226-230.

Gallien, I., Caurant, F., Bordes, M., Bustamante, P., Miramand, P., Fernandez, B., Quellard, N., Babin, P., 2001. Cadmium-containing granules in kidney tissue of the Atlantic white-sided dolphin (Lagenorhyncus acutus) off the Faroe Islands. Comparative Biochemistry and Physiology 130, 389-395.

Garrigue C., Fernandez J.M., Badie J.M., Bernard Ch., Greaves J., Rivaton, J., Trescinski M. 2000. Impact of the human activities in short-finned pilot whales (Globicephala macrorhynchus) and pygmy sperm whale (Kogia breviceps) of the South West Pacific ocean by mesuring Cs-137, K-40 and Pb-210. In: Fernandez J.M, Fichez R. (Eds.), Environmental changes and Radioactive tracers. IRD Editions, Paris, pp 49-58. 
Gaskin, D.E., Smith, G.J.D., Arnold, P.W., Louisy, M.V., Franck, R., Holdrinet, M., McWade, J.W., 1974. Mercury, DDT, dieldrin, and PCB in two species of Odontoceti (Cetacea) from St Lucia, Lesser Antilles. Journal of the Fisheries Research Board Canada 31(7), 1235-1239.

Hansen, J.C., Reske-Nielsen, E., Thorlacius-Ussing, O., Rungby, J., Danscher, G., 1989. Distribution of dietary mercury in a dog. Quantification and localization of total mercury in central and nervous system. The Science of the Total Environment 78, 23-43.

Henry, J., Best, P., 1999. A note on concentrations of metals in cetaceans from southern Africa. In: Reijnders, P.J.H., Aguilar, A., Donovan, G.P. (Eds.), Chemical pollutants and cetaceans. Journal of Cetacean Research and Management (Special Issue 1), Cambridge, p177-194.

Hohn A.A., Fernandez, S., 1999. Bias in dolphin age structure due to age estimation technique. Marine Mammal Science 15(4), 1124-1132.

Holsbeck, L., Joiris, C.R., Debacker, V., Ali, I.B., Roose, P., Nellissen, J.P., Gobert, S., Bouquegneau, J.M., Bossicart, M., 1999. Heavy metals, organochlorines and polycyclic aromatic hydrocarbons in sperm whales stranded in the Southern North Sea during the 1994/1995 winter. Marine Pollution Bulletin 38(4), 304-313.

Honda, K. 1985. Studies on bioaccumulation of heavy metals in marine mammals. Ph D Thesis, Tokyo university (in Japanese).

Itano, K., Kawai, S., Miyazaki, N., Tatsukawa, R., Fujiyama, T., 1984. Mercury and selenium levels in striped dolphins caught off the Pacific coast of Japan. Agriculture and Biological Chemistry 48(5), 1109-1116.

Kemper, C., Gibbs, P., Obendorf, D., Marvanek, S., Lenghaus, C., 1994. A review of heavy metal and organochlorine levels in marine mammals in Australia. The Science of the Total Environment 154, 129-139. 
Koeman, J.H., Peeters, V.H.M., Koudstaal-Hol, C.H.M., Tijoe, P.S., De Goeu, J.J.M., 1973. Mercury selenium correlation in marine mammals. Nature 246, 385-386.

Law, R.J., Jones, B.R., Baker, J.R., Kennedy, S., Milnes, R., Morris, R.J., 1992. Trace metals in the livers of marine mammals from the Welsh coast and the Irish Sea. Marine Pollution Bulletin 24(6), 296-304.

Law, R.J., Allchin, C.R., Jones, B.R., Jepson, P.D., Baker, J.R., Spurrier, C.J.H., 1997. Metals and organochlorines in tissues of a Blainville's beaked whale (Mesoplodon densirostris) and a killer whale (Orcinus orca) stranded in the United Kingdom. Marine Pollution Bulletin 34(3), 208-212.

Law, R.J., Bennett, M.E., Blake, S.J., Allchin, C.R., Jones, B.R., Spurrier, C.J.H., 2001. Metals and organochlorines in pelagic cetaceans stranded on the coasts of England and Wales. Marine Pollution Bulletin 42(6), 522-526.

Mackey, E.A., Demilralp, R., Becker, P.R., Greenberg, R.R., Koster, B.J., Wise, S.A., 1995. Trace element concentrations in cetacean liver tissues archived in the National Marine Mammal Tissue Bank. The Science of the Total Environment 175, 25-41.

Mackey, E.A., Becker, P.R., Demilralp, R., Greenberg, R.R., Koster, B.J., Wise, S.A., 1996. Bioaccumulation of vanadium and other trace metals in livers of Alaskan cetaceans and pinnipeds. Archives of Environmental Contamination and Toxicology 30, 503-512.

McAlpine, D.F. 2001. Pygmy and dwarf sperm whales. In: W.F. Perrin, B. Würsig, J.G.M. Thewissen (Eds.), Encyclopedia of Marine Mammals. Academic Press, New York, p.10071009.

Marcovecchio, J.E., Moreno, V.J., Bastida, R.O., Gerpe, M.S., Rodriguez, D.H., 1990. Tissue distribution of heavy metals in small cetaceans from the South-western Atlantic Ocean. Marine Pollution Bulletin 21(6), 299-304.

Martoja, R., Berry, J.P., 1980. Identification of tiemannite as a probable product of delmethylation of mercury by selenium in cetaceans. Vie Milieu 30, 7-10. 
Monniot, F., Martoja, R., Monniot, C., 1994. Cellular sites of iron and nickel accumulation in ascidians related to the naturally and anthropic enriched New Caledonian environment. Annales de l'Institut Océanographique 70(2), 205-216.

Nigro, M., Leonzio, C., 1996. Intracellular storage of mercury and selenium in different marine vertebrates. Marine Ecology Progress Series 135, 137-143.

Nielsen, H.G., 1972. Age determination of the harbour porpoise, Phocoena phocoena (L.) (Cetacea). Vidensk. Medd Dan. Naturhist. Foren. 135, 61-84.

Nielsen, C.O., Dietz, R., 1990. Distributional pattern of zinc, cadmium, mercury, and selenium in livers of hooded seals (Cystophora cristata). Biol Trace Elem Res 24, 61-71.

Odell, D.K., Asper, E.D., 1976. Studies on the biology of Kogia (Cetacea : Physeteridae) in Florida : preliminary report to the Small Whales Subcommittee on the International Whaling Commission, London.

Olson, P.A., Reilly, S.B., 2001. Pilot whales. In: W.F. Perrin, B. Würsig, J.G.M. Thewissen (Eds.), Encyclopedia of Marine Mammals. Academic Press, New York, p.898-903

Palmisano, F., Cardellicchio, N., Zambonin, P.G., 1995. Speciation of mercury in dolphin liver : a two-stage mechanism for the demethylation accumulation process and role of selenium. Marine Environmental Research 40(2), 109-121.

Pauly, D., Trites, A.W., Capuli, E., Christensen, V., 1998. Diet composition and trophic levels of marine mammals. ICES Journal of Marine Science 55, 467-481.

Pelletier, E., 1985. Mercury-selenium interactions in aquatic organisms: a review. Marine Environmental Research 18, 111-132.

Perrin, W.F., Myrick, A.C.Jr., 1980. Age determination of toothed whales and sirenians. Reports of the International Whaling Commission. Special issue 3, Cambridge, 218 p. 
Plön, S. (in prep.) The natural history and status of pygmy (Kogia breviceps) and dwarf (Kogia sima) sperm whales off Southern Africa. PhD Thesis. Rhodes University, Grahamstown, South Africa.

Robineau, D., Rancurel, P., 1981. Sur deux spécimens du genre Kogia (Cetacea, Physeteridae) en Nouvelle-Calédonie. Zeitschrift für Säugetierkunde 46, 56-58.

Stoneburner, D.L., 1978. Heavy metals in tissues of stranded short-finned pilot whales. The Science of the Total Environment 9, 293-297.

Storelli, M.M., Zizzo, N., Marcotrigiano, G.O., 1999. Heavy metals and methylmercury in tissues of Risso's dolphin (Grampus griseus) and Cuvier's beaked whale (Ziphius cavirostris) stranded in Italy (South Adriatic Sea). Bulletin of Environmental Contamination and Toxicology 63, 703-710.

Sylvestre, J.P. 1988. On a specimen of pygmy sperm whale Kogia breviceps (Blainville, 1838) from New Caledonia. Aquatic Mammals 14, 76-77.

Thompson, D.R., 1990. Heavy metals in marine vertebrates. In: Furness, R.W., Rainbow, P.S., (Eds.), Heavy metals in the marine environment. CRC Press Inc., Boca Raton, p143-182.

Uthe, J.F., Solomon, J., Grift, B., 1972. Rapid semimicro method for the determination of methyl mercury in fish tissue. J Assoc Off Anal Chem 55, 583-589.

Wagemann, R., Trebacz, E., Boila, G., Lockhart, W.L., 1998. Methylmercury and total mercury in tissues of arctic marine mammals. The Science of the Total Environment 218, 1931. 

Table 1. Comparison of trace elements concentrations ( $\mu \mathrm{g} \cdot \mathrm{g}^{-1}$ dry wt) of certified standards from the NRCC determined in the present study with certified values.

\begin{tabular}{|lcccccc|}
\hline Metals & \multicolumn{2}{c}{ DOLT-2 $(\mathrm{n}=6)$} & \multicolumn{2}{c|}{ DORM-2 $(\mathrm{n}=3)$} & \multicolumn{2}{c|}{ DORM-1 $(\mathrm{n}=3)$} \\
& Certified values & Present study & Certified values & Present study & Certified values & Present study \\
\hline $\mathrm{Al}$ & - & - & - & - & - & $13.1 \pm 2.1$ \\
$\mathrm{Cd}$ & $20.8 \pm 0.5$ & $21.4 \pm 0.6$ & $0.043 \pm 0.008$ & $0.042 \pm 0.012$ & - & - \\
$\mathrm{Co}$ & - & - & - & - & $0.049 \pm 0.014$ & $<\mathrm{QL}$ \\
$\mathrm{Cr}$ & - & - & - & - & $3.60 \pm 0.40$ & $3.45 \pm 0.17$ \\
$\mathrm{Cu}$ & $25.8 \pm 1.1$ & $26.9 \pm 1.3$ & $2.34 \pm 0.16$ & $2.28 \pm 0.24$ & $5.22 \pm 0.33$ & $5.24 \pm 0.05$ \\
$\mathrm{Fe}$ & - & - & - & - & $63.6 \pm 4.9$ & $66.7 \pm 1.4$ \\
$\mathrm{Total} \mathrm{Hg}$ & $2.14 \pm 0.28$ & $2.13 \pm 0.02$ & $4.64 \pm 0.26$ & $4.50 \pm 0.16$ & - & - \\
$\mathrm{Organic} \mathrm{Hg}$ & $0.693 \pm 0.053$ & $0.759 \pm 0.018$ & $4.47 \pm 0.32$ & $4.38 \pm 0.28$ & - & - \\
$\mathrm{Mn}$ & - & - & - & - & $1.32 \pm 0.26$ & $1.11 \pm 0.02$ \\
$\mathrm{Ni}$ & - & - & - & - & $1.20 \pm 0.30$ & $0.97 \pm 0.08$ \\
$\mathrm{Se}$ & $6.06 \pm 0.49$ & $5.48 \pm 0.13$ & $1.40 \pm 0.09$ & $1.31 \pm 0.15$ & - & - \\
$\mathrm{Zn}$ & $85.8 \pm 2.5$ & $83.6 \pm 3.4$ & $25.6 \pm 2.3$ & $26.2 \pm 2.1$ & $21.3 \pm 1.0$ & $21.1 \pm 1.3$ \\
\hline
\end{tabular}


Table 2. Characteristics of the odontocetes and preys identified in their stomach contents. Age is the mean $\pm \mathrm{SD}$ of 3 counting of growth layer groups.

\begin{tabular}{|c|c|c|c|c|}
\hline Species & Sex & Length $(\mathrm{m})$ & Age & Prey identified in the stomach content \\
\hline \multirow{15}{*}{$\begin{array}{l}\text { Globicephala } \\
\text { macrorhynchus }\end{array}$} & \multirow{14}{*}{ 入 } & \multirow{14}{*}{5.4} & \multirow{14}{*}{$14 \pm 1$} & Fishes : \\
\hline & & & & Bathyclupea malayana (Bathuclupeidae) \\
\hline & & & & Antigoniia sp. (Caproidae) \\
\hline & & & & Synagrops sp. (Acropomatidae) \\
\hline & & & & Diaphus sp. (Myctophidae) \\
\hline & & & & Cubiceps sp. (Nomeidae) \\
\hline & & & & Chlorophthalmus sp.(Clotophthalmidae) \\
\hline & & & & Cephalopods : \\
\hline & & & & Stenoteuthis sp. (Ommastrephidae) \\
\hline & & & & 3 unidentified species (Ommastrephidae) \\
\hline & & & & Moroteuthis sp. (Onychoteuthidae) \\
\hline & & & & Lycoteuthis sp. (Lycoteuthidae) \\
\hline & & & & Histioteuthis sp. (Histioteuthidae) \\
\hline & & & & 5 unidentified species (Histioteuthidae) \\
\hline & q & 3.5 & $12 \pm 2$ & Empty stomach \\
\hline \multirow{17}{*}{ Kogia breviceps } & \multirow{8}{*}{$\sigma^{\lambda}$} & \multirow{8}{*}{3.1} & \multirow{8}{*}{$6 \pm 1$} & Shrimps : \\
\hline & & & & Pasiphea sp. (Pasiphaeidae) \\
\hline & & & & Gnathophausia ingens (Mysidacea) \\
\hline & & & & Meningodora sp. (Oplophoridae) \\
\hline & & & & Cephalopods : \\
\hline & & & & Histioteuthis sp. (Histioteuthidae) \\
\hline & & & & Enoploteuthis sp. (Enoploteuthidae) \\
\hline & & & & 2 unidentified species \\
\hline & \multirow{9}{*}{ q } & \multirow{9}{*}{3.0} & \multirow{9}{*}{$19 \pm 3$} & Shrimps : \\
\hline & & & & Pasiphea sp. (Pasiphaeidae) \\
\hline & & & & Gnathophausia ingens (Mysidacea) \\
\hline & & & & Meningodora sp. (Oplophoridae) \\
\hline & & & & Cephalopods : \\
\hline & & & & Taonius sp. (Cranchidae) \\
\hline & & & & Histioteuthidae \\
\hline & & & & Enoploteuthidae \\
\hline & & & & Octopoteuthidae \\
\hline
\end{tabular}


Table 3. Age and metal concentrations $\left(\mu \mathrm{g} \cdot \mathrm{g}^{-1} \mathrm{dwt}\right.$ ) in the tissues of odontocetes from the New Caledonia.

\begin{tabular}{|c|c|c|c|c|c|c|c|c|c|c|c|c|c|c|}
\hline Tissue & Age & $\mathrm{Al}$ & $\mathrm{Cd}$ & Co & $\mathrm{Cr}$ & $\mathrm{Cu}$ & $\mathrm{Fe}$ & Total-Hg & Organic-Hg & $\mathrm{Mn}$ & $\mathrm{Ni}$ & $\mathrm{Se}$ & V & $\mathrm{Zn}$ \\
\hline 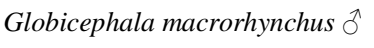 & $14 \pm 1$ & & & & & & & & & & & & & \\
\hline Liver & & $1.38 \pm 0.45$ & $225.3 \pm 0.4$ & $<\mathrm{dl}$ & $<\mathrm{dl}$ & $37.4 \pm 0.3$ & $1472 \pm 7$ & $1411 \pm 24$ & $11.7 \pm 0.4$ & $7.1 \pm 0.2$ & $<\mathrm{dl}$ & $627 \pm 43$ & 0.06 & $135.7 \pm 0.6$ \\
\hline Muscle & & $2.62 \pm 0.69$ & $0.79 \pm 0.03$ & $<\mathrm{dl}$ & $<\mathrm{dl}$ & $0.8 \pm 0.1$ & $347 \pm 29$ & $32.8 \pm 2.0$ & $4.41 \pm 0.09$ & $<\mathrm{dl}$ & $<\mathrm{dl}$ & $9 \pm 1$ & $<\mathrm{dl}$ & $61.1 \pm 2.4$ \\
\hline Blubber & & $1.53 \pm 0.14$ & $0.95 \pm 0.03$ & $<\mathrm{dl}$ & $2.51 \pm 0.01$ & $0.4 \pm 0.1$ & $187 \pm 8$ & $11.0 \pm 0.8$ & $0.47 \pm 0.05$ & $0.17 \pm 0.01$ & $<\mathrm{dl}$ & $4 \pm 1$ & $<\mathrm{dl}$ & $21.3 \pm 0.3$ \\
\hline G. macrorhynchus ? & $12 \pm 2$ & & & & & & & & & & & & & \\
\hline Liver & & $1.07 \pm 0.11$ & $464.4 \pm 5.4$ & 0.04 & $<\mathrm{dl}$ & $51.0 \pm 1.3$ & $1535 \pm 17$ & $1452 \pm 79$ & $1.70 \pm 0.01$ & $6.8 \pm 0.2$ & $<\mathrm{dl}$ & $758 \pm 39$ & 0.10 & $113.3 \pm 2.1$ \\
\hline Muscle & & $0.88 \pm 0.26$ & $1.48 \pm 0.03$ & $<\mathrm{dl}$ & $<\mathrm{dl}$ & $1.5 \pm 0.1$ & $622 \pm 78$ & $27.3 \pm 1.1$ & $3.29 \pm 0.06$ & $<\mathrm{dl}$ & $<\mathrm{dl}$ & $6 \pm 1$ & $<\mathrm{dl}$ & $49.8 \pm 1.4$ \\
\hline Blubber & & $1.15 \pm 0.00$ & $0.84 \pm 0.01$ & $<\mathrm{dl}$ & $0.32 \pm 0.08$ & $0.2 \pm 0.1$ & $18 \pm 2$ & $3.20 \pm 0.22$ & $0.21 \pm 0.02$ & $<\mathrm{dl}$ & $<\mathrm{dl}$ & $3 \pm 0$ & $<\mathrm{dl}$ & $17.3 \pm 1.3$ \\
\hline Kogia breviceps $\widehat{\widehat{O}}$ & $6 \pm 1$ & & & & & & & & & & & & & \\
\hline Liver & & $2.11 \pm 0.29$ & $28.8 \pm 0.8$ & $<\mathrm{dl}$ & $<\mathrm{dl}$ & $8.1 \pm 0.1$ & $2503 \pm 11$ & $7.86 \pm 0.14$ & $1.25 \pm 0.12$ & $5.2 \pm 0.2$ & $<\mathrm{dl}$ & $21 \pm 1$ & 0.10 & $52.3 \pm 1.6$ \\
\hline Muscle & & $6.58 \pm 0.17$ & $0.41 \pm 0.01$ & $<\mathrm{dl}$ & 0.03 & $1.7 \pm 0.2$ & $977 \pm 18$ & $6.07 \pm 0.17$ & $4.65 \pm 0.01$ & $0.26 \pm 0.01$ & $<\mathrm{dl}$ & $6 \pm 1$ & $<\mathrm{dl}$ & $42.9 \pm 0.7$ \\
\hline K. breviceps ㅇ & $19 \pm 3$ & & & & & & & & & & & & & \\
\hline Liver & & $17.0 \pm 0.5$ & $47.5 \pm 1.3$ & 0.05 & $<\mathrm{dl}$ & $17.5 \pm 0.9$ & $3120 \pm 84$ & $77.3 \pm 0.7$ & $7.03 \pm 0.06$ & $5.0 \pm 0.1$ & $<\mathrm{dl}$ & $25 \pm 1$ & 0.68 & $54.3 \pm 0.8$ \\
\hline Muscle & & $3.60 \pm 0.33$ & $0.57 \pm 0.04$ & $<\mathrm{dl}$ & $<\mathrm{dl}$ & $0.9 \pm 0.0$ & $820 \pm 12$ & $5.16 \pm 0.13$ & $3.75 \pm 0.11$ & $0.12 \pm 0.02$ & $<\mathrm{dl}$ & $3 \pm 0$ & $<\mathrm{dl}$ & $67.1 \pm 0.9$ \\
\hline
\end{tabular}

dl : detection limit.

wet : dry wt ratio are 4.5, 4.0 and 1.6 for liver, muscle and blubber, respectively. 


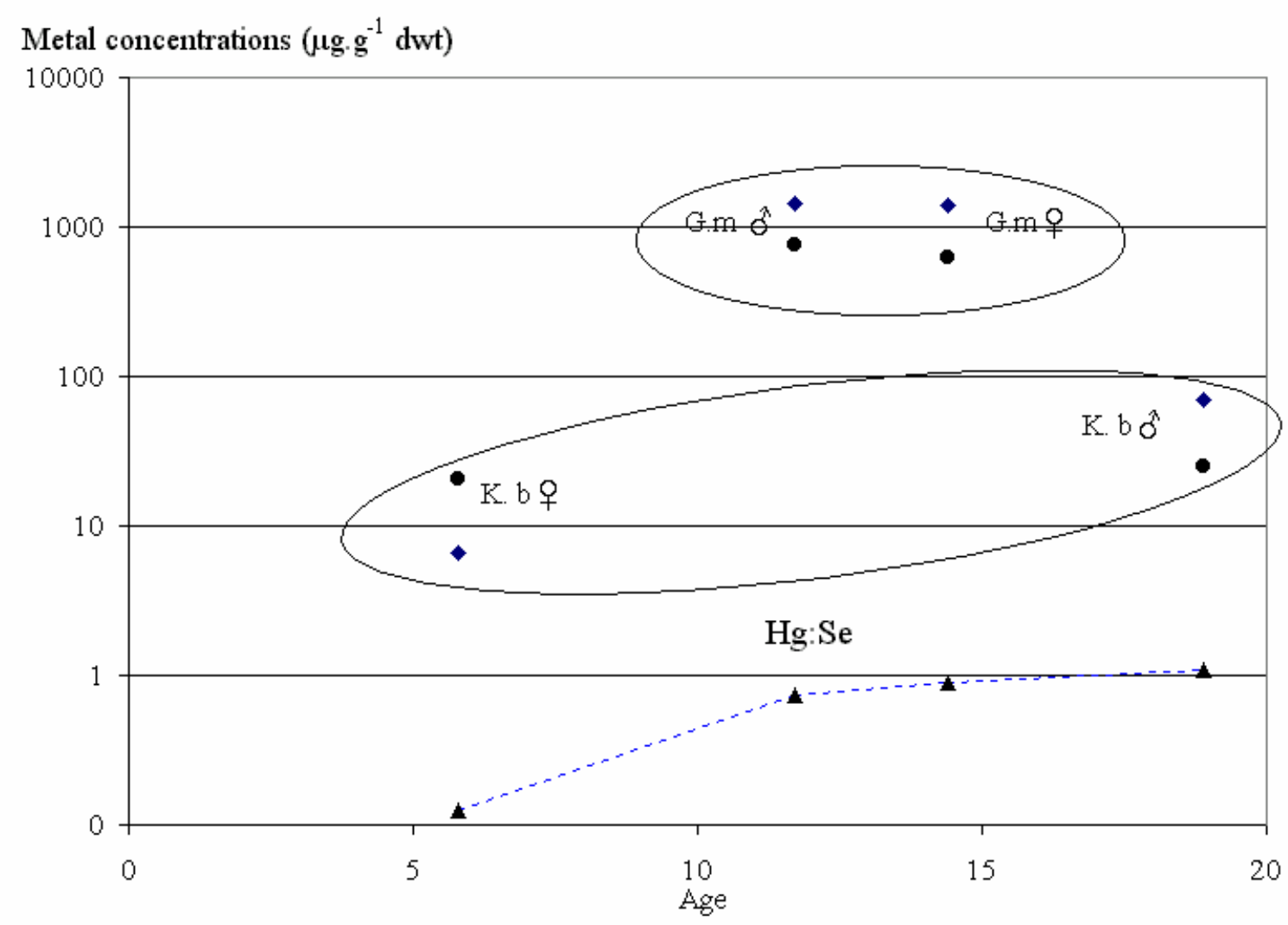

Figure 1. Concentrations of inorganic $\mathrm{Hg}(\diamond)$ and $\mathrm{Se}(\boldsymbol{\bullet})$ together with Se:Hg molar ratio (A) in G. macrorhynchus and K. breviceps from New Caledonia.

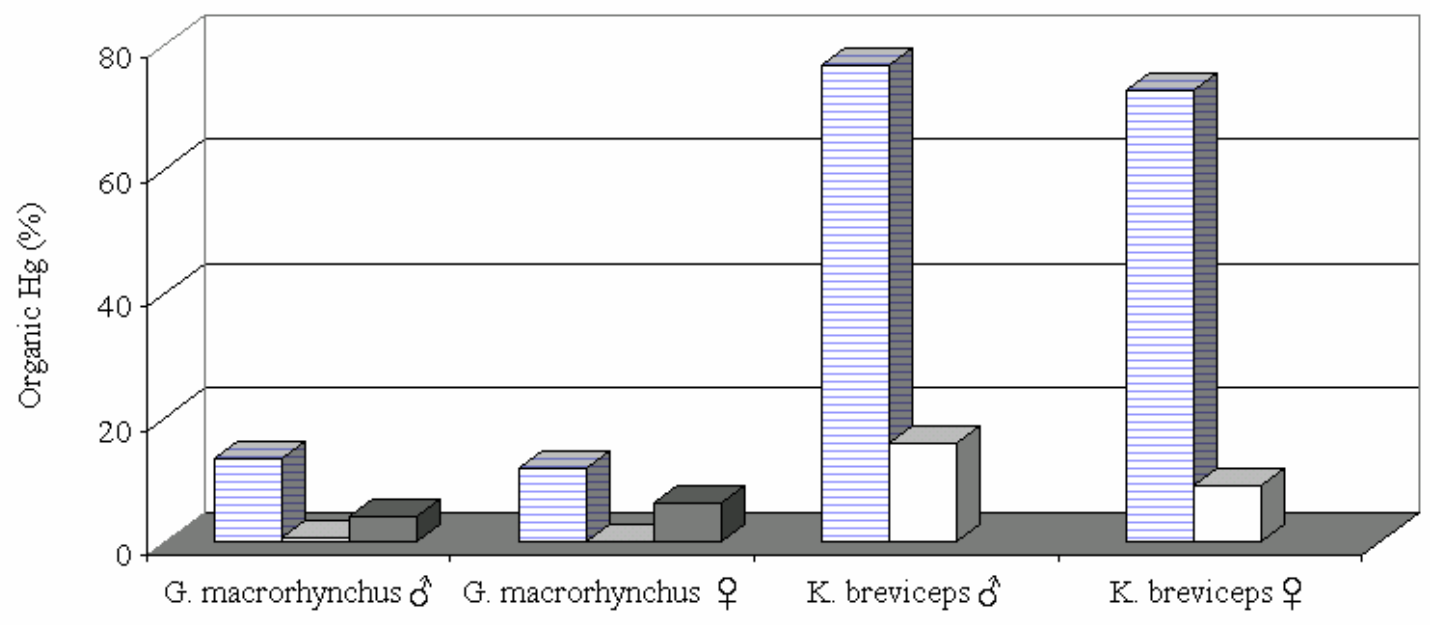

Figure 2. Percentage of organic Hg in the muscle (striped), liver (white) and blubber (grey) of G. macrorhynchus and K. breviceps from New Caledonia. 
Table 4. Heavy metal concentrations $\left(\mu \mathrm{g} \cdot \mathrm{g}^{-1}\right.$ wwet) in the liver of odontocete species from various areas.

\begin{tabular}{|c|c|c|c|c|c|c|c|c|c|c|c|c|c|c|}
\hline Species & Locality & $\mathrm{N}$ & $\mathrm{Cd}$ & Co & $\mathrm{Cr}$ & $\mathrm{Cu}$ & $\mathrm{Fe}$ & Total-Hg & Organic-Hg & $\mathrm{Mn}$ & $\mathrm{Ni}$ & $\mathrm{Se}$ & $\mathrm{Zn}$ & Authors \\
\hline Globicephala melas & Northwest Atlantic Ocean & 9 & $7.88 \pm 3.61$ & $0.012 \pm 0.003$ & - & $2.7 \pm 1.0$ & $356 \pm 221$ & $40.30 \pm 38.81$ & - & $2.53 \pm 0.51$ & - & $11.73 \pm 9.94$ & $39 \pm 7$ & Mackey et al. 1995 \\
\hline G. melas & Northeast Atlantic Ocean & 1 & 0.1 & - & 0.25 & 4.7 & 2680 & 0.74 & - & - & 0.31 & 2.1 & 45 & Law et al. 2001 \\
\hline Grampus griseus & Mediterranean Sea & 1 & 6.00 & - & 0.28 & - & - & 1002 & 14.70 & - & - & 266.4 & - & Storelli et al. 1999 \\
\hline G. griseus & " & 1 & 8.42 & - & 0.41 & - & - & 478.3 & 7.35 & - & - & 113.2 & - & Storelli et al. 1999 \\
\hline G. griseus & Northeast Atlantic Ocean & 1 & 0.2 & - & 0.26 & 5.2 & 337 & 2.6 & - & - & 0.71 & 4.6 & 37 & Law et al. 2001 \\
\hline Lagenorhynchus acutus & Northwest Atlantic Ocean & 4 & $0.423 \pm 0.294$ & $0.013 \pm 0.029$ & - & $6.3 \pm 2.2$ & $179 \pm 100$ & $10.36 \pm 10.09$ & - & $3.67 \pm 0.53$ & - & $5.31 \pm 2.98$ & $41.6 \pm 9.9$ & Mackey et al. 1995 \\
\hline Mesoplodon bidens & Northeast Atlantic Ocean & 1 & 20 & - & 1.7 & 19 & 172 & 322 & - & - & 1.0 & 133 & 83 & Law et al. 2001 \\
\hline M. densirostris & $"$ & 1 & 6.2 & - & 0.63 & 5.6 & & 248 & - & - & 0.75 & 98 & 41 & Law et al. 1997 \\
\hline Phocoena phocoena & Northwest Atlantic Ocean & 6 & $0.444 \pm 0.281$ & $0.006 \pm 0.003$ & - & $8.9 \pm 4.0$ & $388 \pm 116$ & $9.86 \pm 15.17$ & - & $4.49 \pm 0.93$ & - & $2.04 \pm 1.19$ & $28 \pm 5$ & Mackey et al. 1995 \\
\hline Stenella coeruleoalba & Mediterranean Sea & 6 & $1.75 \pm 1.27$ & - & $0.03 \pm 0.02$ & $7.73 \pm 2.22$ & $307 \pm 93$ & $189.2 \pm 28.6$ & $8.82 \pm 3.70$ & $3.19 \pm 1.48$ & - & $80.3 \pm 12.7$ & $24.5 \pm 7.3$ & Cardellicchio et al. 2000 \\
\hline Physeter macrocephalus ${ }^{\mathrm{a}}$ & North Sea & 6 & $19.1 \pm 8.9$ & - & $0.02 \pm 0.02$ & $1.7 \pm 0.6$ & $458 \pm 70$ & $14.5 \pm 9.2$ & $0.34 \pm 0.16$ & - & $0.12 \pm 0.10$ & $3.6 \pm 2.6$ & $21 \pm 3$ & Holsbeck et al. 1999 \\
\hline Ziphius cavirostris & Mediterranean Sea & 1 & 18.49 & - & 0.12 & - & - & 259.3 & 9.85 & - & - & 110.6 & - & Storelli et al. 1999 \\
\hline
\end{tabular}

Table 5. Heavy metal concentrations ( $\mu \mathrm{g} . \mathrm{g}^{-1}$ wwet) in the liver of G. macrorhynchus and K. breviceps from various areas.

\begin{tabular}{|c|c|c|c|c|c|c|c|c|c|c|c|c|c|c|}
\hline Species & Locality & $\mathrm{N}$ & $\mathrm{Cd}$ & Co & $\mathrm{Cr}$ & $\mathrm{Cu}$ & $\mathrm{Fe}$ & Total-Hg & Organic-Hg & $\mathrm{Mn}$ & $\mathrm{Ni}$ & $\mathrm{Se}$ & $\mathrm{Zn}$ & Authors \\
\hline \multicolumn{15}{|c|}{ Globicephala macrorhynchus } \\
\hline & Australia & 5 & $0.4-22.0$ & - & - & - & - & - & - & - & - & - & - & Kemper et al. 1994 \\
\hline & Cumberland Island & 4 & $13.90 \pm 3.98$ & - & - & - & - & $231.0 \pm 172.1$ & - & - & - & $44.18 \pm 19.32$ & - & Stoneburner 1978 \\
\hline & New Caledonia & 2 & $50.1-102.3$ & 0.01 & $<\mathrm{dl}$ & $8.7-12.7$ & $294-307$ & $313-323$ & $0.38-2.59$ & $1.51-1.57$ & $<\mathrm{dl}$ & $146-162$ & $35.3-37.0$ & Present study \\
\hline \multicolumn{15}{|c|}{ Kogia breviceps } \\
\hline & Argentina & 1 & 7.6 & - & - & 10.3 & - & 11.7 & & - & - & - & 163.2 & Marcovecchio et al. 1990 \\
\hline & Australia & 1 & 14.3 & - & - & - & - & 1.52 & - & - & - & - & - & Kemper et al. 1994 \\
\hline & England & 1 & 3.2 & - & 0.57 & 9.5 & 1450 & 14 & - & - & 0.68 & 0.18 & 21 & Law et al. 2001 \\
\hline & Florida & - & $0.22-7.60$ & - & $0.84-4.13$ & $2.10-144.44$ & - & - & - & $0.80-4.06$ & - & - & $10.09-15.04$ & Odell \& Asper 1976 \\
\hline & New Caledonia & 2 & $6.3-10.8$ & 0.01 & $<\mathrm{dl}$ & $1.9-4.1$ & $501-624$ & $1.7-17.2$ & $0.28-1.56$ & $1.11-1.15$ & $<\mathrm{dl}$ & $4.5-5.7$ & $16.9-18.1$ & Present study \\
\hline & South Africa & 4 & - & - & - & - & - & $0.9 \pm 0.8$ & - & - & - & - & $28.5 \pm 13.7$ & Henry \& Best 1999 \\
\hline & South Africa & 7 & - & - & - & - & - & $6.1 \pm 5.6$ & - & - & - & - & $21.9 \pm 4.7$ & Henry \& Best 1999 \\
\hline
\end{tabular}


